after 1987 when she was diagnosed as having terminal colon cancer.

She was active in the Policy Studies Organization. She provided a house and office equipment in Champaign, Illinois, which is now the headquarters of PSO. She also edited three PSO symposia dealing with dispute resolution, biomedical policy, and health-care insurance. She helped on numerous other PSO symposia and training workshops partly by providing research funding when no other funding sources were available.

Her work is being continued at the Miriam K. Mills Research Center for Super-Optimizing Analysis and Developing Nations at the University of Illinois. Super-optimizing analysis involves methods designed to lead to alternatives to public policy problems whereby conservatives, liberals, and other major viewpoints can all come out ahead of their best initial expectations simultaneously.

Her temporarily unfinished work emphasizes health care and women's rights in developing countries. JAI Press will be publishing in 1993 her volume on Health Issues in Developing Nations in the 21-volume treatise on Policy Studies and Developing Nations. Her volume on Women and Developing Nations is being continued by others.

Miriam Mills also wrote poetry and inspirational literature. Her book The Penny Diary: Countering Illness (Broadside Press, 1991) has been favorably received by other cancer patients. Her poetry book entitled The Kites of Hope (Ryza Press, 1966) contains a poem called "Hope" which ends with the lines "I stumble in the shadow of the brightest sun, but I exalt in the brightness of my dreams to be done."

Stuart S. Nagel

University of Illinois

\section{Thornton C. Sinclair}

Thornton C. Sinclair, professor emeritus at the University of Houston, died on October 4, 1991, at the age of 87. Born in Ft. Thomas, Kentucky on February 20, 1904,
Thornton retained the gentleness of his southern background throughout his life. He received a bachelor's degree in 1925 from Miami University in Ohio, an LLB from Columbia University in 1931, and the Ph.D. in government from Harvard University in 1935. His earliest teaching positions were at Transylvania College in Lexington, Kentucky and Newark College of Rutgers University. As a young man Thornton traveled often to Europe where he met his wife Marga, a plastic surgeon. They moved to Houston in 1950 so that she could take a position at the Texas Medical Center and he could join the faculty of the University of Houston. In the mid-1950s Thornton became chairman of the Department of Political Science. He was an active member of the university community and the political science profession until his retirement in 1973. Thornton's scholarly interests centered on constitutional law and judicial politics. He co-authored two monographs, The Constitution of Texas with Werner F. Grunbaum and The Selection of Judges in Texas with Bancroft C. Henderson.

Thornton was a scholar in the manner of what some think of as the "old school." He was a person of deep conviction but very gentle in his expression. He persuaded with reasoned argument, not passion. Indeed in the years of working for civil liberties, academic freedom and intellectual excellence, he advanced his causes with good humor and consideration for those who might not share his views. He was popular with students because he was as concerned about their performance as he was the subjects he taught. Thornton was an award-winning teacher at the university.

Thornton had a lifelong interest in and involvement with politics.

Although a dedicated Democrat, he had as many friends among Republicans as among Democrats. He is survived by three daughters (Barbara, a political scientist; Julia, a businesswoman; and Nora, a language teacher), seven grandchildren, two great grandchildren and countless friends.

Joseph L. Nogee

University of Houston

\section{Albert P. Vannucci}

Albert P. Vannucci, associate professor of political science and director of international studies at the University of Pittsburgh at Johnstown, suffered a heart attack and died on March 21, 1992. He was 42.

Al was born in Lock Haven, Pennsylvania and completed preparatory school at St. Joseph's in Williamsport. He received his B.S. degree in history from the University of Scranton and went on to Georgetown University Law Center in Washington, D.C. After one year of law school, Al shifted to the School of International Service at the American University, receiving his M.A. in international studies in 1974. He completed his $\mathrm{Ph}$.D. in political science at the New School for Social Research four years later in 1978.

After four years at Spring Hill College in Mobile, Alabama, $\mathrm{Al}$ became an assistant professor of political science at the University of Pittsburgh at Johnstown. Within five years, he built an international studies certificate program from scratch and developed affiliations with study abroad programs and exchange programs with several colleges in Washington, D.C. A large number of his advisees served substantive internships in Washington and went on to graduate programs in international studies. Several of them are currently foreign policy advisory staff in the U.S. House and Senate.

His greatest efforts were devoted to internationalizing the UPJ curriculum and student activities on campus. He founded and directed the Student Council on World Affairs, a group that has been instrumental in bringing speakers to campus, in pursuing philanthropic projects to assist the alleviation of world hunger and the plight of political prisoners abroad, and in coordinating a huge Ethnic Festival held on campus each spring. He secured numerous grants for curriculum development in international studies and foreign languages, including the financing of satellite hookups to access international broadcasts. In recent years, Al secured sponsorship for and hosted two Fulbright Scholars-inResidence at UPJ, one from China and another from Japan. At the time 
of his death, he was trying to develop funding sources for scholarships for UPJ students who wanted to study abroad.

$\mathrm{Al}$ always lamented not being able to devote more time and attention to his scholarly agenda, but his extensive commitments to students and the campus made that very difficult. $\mathrm{He}$ published a large number of reviews across the range of international studies and in his principal field of Latin America. His research on U.S.Argentine Relations led to an article in the Journal of Latin American Studies in 1986 and the co-editing (with Neale Ronning of the New School) of Ambassadors and Foreign Policy: The Influence of Legislative Reform on Defence Accountability in Britain and America (Praeger, 1987). At the time of his death, he had begun working on a book-length manuscript on the politics of development.
Al's enduring legacy, however, is destined to be his impact on undergraduate students over the seven years he was at UPJ. He was always one of the most sought-after instructors in the college, and in 1985 was named one of eight recipients of the Chancellor's Distinguished Teaching Award at the University of Pittsburgh. In 1988 he received an Undergraduate Teaching Fellowship to work with students to develop foreign policy decision-making simulations.

On April 8, 1992, a memorial mass was held at the J. Irving Whalley Chapel on the campus of the University of Pittsburgh at Johnstown. At the end of the mass, Matthew Procter, a graduating political science senior, made the following remarks that seem appropriate for closing this essay:

Inside the classroom, Dr. Vannucci combined an expert's knowledge of the course material with a selfdeprecating humourous style. International studies as a subject is rather complex and new to the first generation college student, but Dr. Vannucci's teaching method made it both understandable and interesting.

He was an objective teacher and careful not to let students know how he personally felt on any particular issue so as not to bias students one way or the other. Anyone who had him for even one class knew that he was cynical about a lot of issues. But Dr. Vannucci's cynicism was a cynicism born of deep idealism, a belief that the students, this university, our country, and indeed even our world could do much better. . . . In his own unique way, he attempted to bring students up to a higher level, and he constantly pushed each student to be the best they could be.

James R. Alexander University of Pittsburgh at Johnstown 